\title{
Body composition in female anorexia nervosa patients
}

\author{
BY M. PROBST ${ }^{1}$, M. GORIS ${ }^{2}$, W. VANDEREYCKEN ${ }^{1}$ \\ AND H. VAN COPPENOLLE ${ }^{1}$ \\ ${ }^{1}$ University Center St Joseph, B-3070 Kortenberg, Belgium \\ ${ }^{2}$ Department of Kinesiology, Catholic University of Leuven, Leuven, Belgium
}

(Received 16 June 1995 - Revised 19 February 1996-Accepted 27 March 1996)

\begin{abstract}
For the first time, body composition has been studied in a very large sample of female anorexia nervosa patients $(\boldsymbol{n} 200)$ using two methods: anthropometry (skinfold thickness) and densitometry (underwater weighing). The concurrent validity of both methods appeared to be good ( $r$ 0.84). Although the mean percentage of body fat (13.5) in our sample corresponds with most of the previous reports, the range (4.3-24.8) is great. Our study shows that BMI is not a good measure of fatness. Age and duration of illness were not related to body fat. Percentage fat was found to be different $(t 2.76, P<0.01)$ according to the diagnostic subtype of anorexia nervosa: restricters (12-9) $v$. bingers and/or purgers (14.7).
\end{abstract}

Anorexia nervosa: Body composition: Anthropometry: Densitometry: Underwater weighing

The decrease in body fat in anorexia nervosa (AN) patients due to a prolonged restriction of oral nutrient intake and weight loss has important physiologial consequences with respect to morbidity and mortality (Russell et al. 1983). Knowledge of body composition in these patients is, therefore, clinically most relevant. Body-composition studies are generally based on the principle that one can estimate the relative proportion of two components: fat mass (FM) and fat-free mass (FFM; water, proteins and minerals). A wide variety of methods, from relatively simple and cheap to sophisticated and expensive ones, are available to measure body composition (for a recent review, see Heymsfield et al. 1995). The published studies on body composition in eating disorders are difficult to compare and mostly based on very small groups. We have found only a few studies (Pirke et al. 1986; Charest-Lilly et al. 1987; Mayo-Smith et al. 1989; Hannan et al. 1990, 1993 a, b; Vaisman et al. 1991; Russell et al. 1994; Young et al. 1994) in which more than fifteen patients have been investigated.

In the context of a large research and treatment project on psychological and physiological aspects of how AN patients feel and think about their own body (Probst $e t$ al. 1995) we applied two methods of body composition assessment: the densitometric technique of underwater weighing (UWW) and the anthropometric approach of measuring skinfold thickness (SFT). UWW is considered to be the method of reference for body composition with reliability coefficients (test-retest correlations) above $r 0.95$ and concurrent validity coefficients usually above $r 0.80$ (Heymsfield et al. 1995). SFT is a classic technique with a generally weaker reliability (but usually above $r 0.90$ ). The standard error for prediction of fat percentage from SFT is in general $2 \cdot 6-3.4 \%$ of body weight, which is not very different from the standard error obtained with UWW. Since SFT measures only subcutaneous adipose tissue, its validity is somewhat lower. The correlation between UWW and SFT ranges from 0.65 to 0.93 (Heymsfield et al. 1995).

The aims of our study were: (1) to estimate body composition in a large group of AN patients who were all in a starvation state; (2) to test the concurrent validity of the methods 
used (UWW and SFT); (3) to study the relationship between FFM and BMI and (4) to assess the impact of age and clinical variables such as duration of illness and diagnostic subtype (restricters $v$. bingers and/or purgers) on body composition.

\section{METHOD}

Subjects

Female patients ( $n$ 200) consecutively admitted between 1988 and 1995 to the Eating Disorder Unit of the University Center St Joseph in Kortenberg (Belgium) participated in the study. They all consented to the overall regimen of our inpatient treatment (Vandereycken \& Meermann, 1984). All met both the DSM-III-R and DSM-IV diagnostic criteria for AN (American Psychiatric Association, 1994) and were classified in two subtypes: the 'restricting' type of AN patients who only lost weight through fasting and eventually rigorous physical exercise ( $n$ 131), and the 'mixed' type of anorectics who (intermittently) showed episodes of binge-eating and/or self-induced vomiting and/or laxative use ( $n$ 69). Patients with concurrent organic illnesses were excluded. At the time of assessment all were amenorrhoeic and not taking oestrogens or other hormonal therapy. Procedures were approved by the Ethical Committee of the University Center (including informed consent from the patients or, in case of minors, from the parents).

\section{Procedure}

All anthropometric and densitometric assessments were executed during the first week of treatment by the same highly experienced female investigator. Height was measured to the nearest $5 \mathrm{~mm}$ using a stadiometer. Body weight was measured, with the subject wearing underclothes only, using a beam balance, to the nearest $100 \mathrm{~g}$. The Quetelet index or BMI $\left(\mathrm{kg} / \mathrm{m}^{2}\right)$ was calculated.

Twelve skinfolds were measured (Weiner \& Lourie, 1969; Brown \& Jones, 1977; Goris, 1984): biceps, triceps, subscapular, suprailiac, chin, side, waist, abdomen, thigh anterior and posterior, calf lateral and medial) using a Harpenden electronic read out (HERO) skinfold caliper (Jones et al. 1979). The precision (test-retest) of our skinfold measurement fluctuated from $r 0.93$ (for thigh posterior) to $r 0.97$ (for the suprailiac; Goris, 1984). The percentage body fat was estimated from the logarithm of the sum of the skinfold measurements taken at four sites (biceps, triceps, subscapular and suprailiac) and the prediction equations, using the age-specific equations (Durnin \& Womersley, 1974). For girls below 16 years we used the same formula as that used for girls below 20 years.

Hydrodensitometry (UWW) calculates body volume as the difference between body weight measured in air and in water (based on Archimedes' principle that body volume is equal to the loss of weight in water). Modern hydrodensitometry systems consist of a scale within a large heated tank of water $\left(37^{\circ}\right)$. The subject exhales maximally, submerges, and body weight is then recorded. The body weight (accurate to the nearest $\pm 10 \mathrm{~g}$ ) in water is measured at least six times. The highest value of the measurements is taken. Body density (D) is calculated by the following formula:

$$
\mathrm{D}=\frac{\mathrm{W}}{\mathrm{W}-\mathrm{Ww} / \mathrm{dw}-(\mathrm{RV}+\mathrm{GI})}
$$

where $\mathrm{W}$ is body weight in air, Ww is body weight in the water (after maximal expiration), $\mathrm{dw}$ is the density of the water, RV is the correction for the residual lung volume (measured 
twice at the time of taking Ww by He dilution), and GI is the correction for the volume of gas in the gastrointestinal tract; $150 \mathrm{ml}$ seems the most appropriate correction (Leusink, 1964; Lasser et al. 1975, 1976; Biersteker et al. 1983). The precision of the measurement (test-retest) in our laboratory is $r 0.96$ (Goris, 1984). The percentage of fat is calculated by the Siri (1956) equation:

$$
\text { percentage fat }=(4 \cdot 95 / \mathrm{D}-4 \cdot 50) \times 100 \text {. }
$$

\section{Data analysis}

Relationships between variables were assessed by Pearson product moment correlations. One-way ANOVA was used for group comparison. Differences found on the one-way ANOVA were evaluated by the Tukey test (for unequal samples, $P<0-01$ ). Within-group differences were evaluated using a two-tailed Student's $t$ test. All data were coded and computerized using Statistica (Statsoft Inc., 1991).

\section{RESULTS}

\section{Comparison of two methods}

The mean percentage of body fat (PBF) estimated by UWW and SFT was $13.5 ; 25 \%$ of the patients had a PBF less than $10,61 \%$ below 15, and $7 \%$ above 20 . As shown in Table 1, SFT and UWW gave approximately the same values (means and standard deviations and ranges) for PBF, FFM, and FM. Indices from the two methods had good correlations: D $r 0.84, P<0.0000$; FFM $r 0.96, P<0.0000$, standard error of estimate (SEE) $1.09 \mathrm{~kg}$; FM $r 0.90, P<0.0000$, SEE $1.04 \mathrm{~kg}$; PBF $r 0.84, P<0.0000$, SEE $2.6 \%$. In addition, a twotailed $t$ test indicated that there were no significant differences between values for PBF $(t 1 \cdot 80$, df 185), FM $(t \cdot 1 \cdot 85$, df 185), and FFM $(t 1 \cdot 58$, df 185$)$ calculated by SFT $v$. UWW.

\section{Relationship between body fat and BMI}

Only $2 \%$ of the AN patients had a BMI higher than 17 , and $67 \%$ had a BMI of 15 or less. The correlation between BMI and PBF estimated by SFT and by UWW was high $(r 0.75$ and 0.72 , SEE 3.1 and $2.8 \%$ respectively). Nevertheless, only 56.2 (SFT) $-51.8 \%$ (UWW) of the variance $\left(r^{2}\right)$ in PBF could be predicted by BMI. PBF data for each BMI point are shown in Table 2. The variations in PBF at any given BMI were great; with a BMI of 13 , for example, the PBF varied from 7 to $17 \%$.

\section{Age and duration of illness}

We expected a higher PBF in older and more chronic patients. Indeed, univariate ANOVA for age confirmed this using UWW $(F(2,183) 7 \cdot 32, P<0.001)$. Post hoc comparison did not show a difference between adolescents $(<19$ years, $n 82)$ and young adults $(20-29$ years, $n 88$ ), but both groups differed significantly from the oldest group ( $>30$ years, $n 30$ ). More detailed analysis of the adolescent group did not reveal differences on PBF between subgroups of ages (years; $14 n 11,15 n 14,16 n 18,17 n 12,18 n 15$ and 19 years $n 12$ ). Unexpectedly, an ANOVA did not show an effect of duration of illness (years; $<3, n 96$, 3-6 $n 39,6-9 n 27,>9 n 42$ ) on PBF measured by UWW.

\section{Restricters $v$. bingers and/or purgers}

The PBF of the mixed type differed significantly from that of the restricting type using UWW $(t 2.8$, df 123,$63 ; P<0 \cdot 000)$. As shown in Table 3 , significant differences were found in all variables except abdomen $\operatorname{SFT}(t 1 \cdot 74$, df 123,63). 
Table 1. Clinical features and body composition in female anorexia nervosa patients (n 200)

(Mean values and standard deviations, with ranges)

\begin{tabular}{|c|c|c|c|}
\hline & Mean & SD & Range \\
\hline Age (years) & $22 \cdot 7$ & $6 \cdot 3$ & $12 \cdot 8-42 \cdot 4$ \\
\hline Duration (years) & $5 \cdot 6$ & $4 \cdot 8$ & $0 \cdot 4-25 \cdot 0$ \\
\hline Weight (kg) & $40 \cdot 3$ & $5 \cdot 7$ & $23 \cdot 4-55 \cdot 4$ \\
\hline Height (m) & 1.64 & $0 \cdot 07$ & $1-40-1 \cdot 80$ \\
\hline BMI $\left(\mathrm{kg} / \mathrm{m}^{2}\right)$ & $14 \cdot 9$ & $1 \cdot 7$ & $10 \cdot 2-18 \cdot 4$ \\
\hline \multicolumn{4}{|l|}{ Densitometry* } \\
\hline Density (g/ml) & 1.0680 & $0 \cdot 0091$ & $1.0426-1.0895$ \\
\hline FFM (kg) & $34 \cdot 89$ & 3.9 & $22 \cdot 2-44 \cdot 4$ \\
\hline Fat mass $(\mathrm{kg})$ & 5.63 & $2 \cdot 3$ & $1 \cdot 2-11 \cdot 4$ \\
\hline Body fat $(\%)$ & $13 \cdot 51$ & $4 \cdot 3$ & $4 \cdot 3-24 \cdot 8$ \\
\hline \multicolumn{4}{|l|}{ Anthropometry* } \\
\hline Density $(\mathrm{g} / \mathrm{ml})$ & 1.0684 & 0.0110 & $1.0443-1.0967$ \\
\hline FFM (kg) & $34 \cdot 75$ & $4 \cdot 1$ & $22 \cdot 7-45 \cdot 7$ \\
\hline Fat mass (kg) & 5.55 & $2 \cdot 4$ & $0.5-11.6$ \\
\hline Body fat $(\%)$ & $13 \cdot 36$ & $4 \cdot 8$ & $1 \cdot 3-24 \cdot 0$ \\
\hline Skinfold sum (mm) & $73 \cdot 64$ & $29 \cdot 1$ & $11 \cdot 69-164 \cdot 9$ \\
\hline
\end{tabular}

FFM, fat-free mass.

* For details of procedures, see pp. 640-641.

Table 2. Percentage body fat for each BMI point in female anorexia nervosa patients* (n 200)

(Mean values and standard deviations, with ranges)

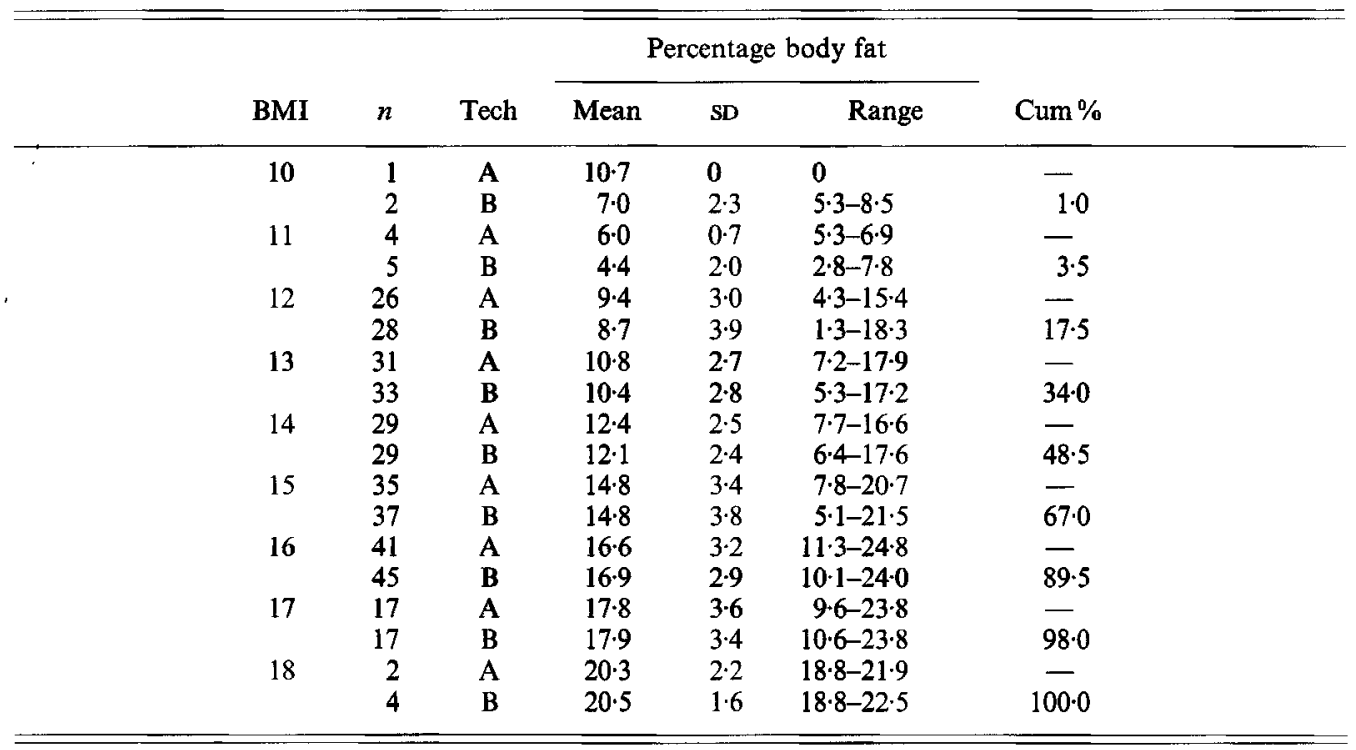

Tech, technique; A, underwater weighing; B, skinfold measures; Cum \%, cumulative percentage of cases (n 200).

* For details of subjects and procedures, see Table 1 and pp. 640-641. 
Table 3. Clinical features and body composition in subgroups of anorexia nervosa $(A N)$ patients (restricters $v$. bingers and/or purgers) $\dagger$

(Mean values and standard deviations)

\begin{tabular}{|c|c|c|c|c|c|}
\hline & \multicolumn{2}{|c|}{ AN restricters } & \multicolumn{2}{|c|}{$\begin{array}{l}\text { AN bingers and/or } \\
\text { purgers }\end{array}$} & \multirow{2}{*}{$\begin{array}{l}\text { Statistical analysis } \\
\text { of difference } \\
\text { (Student's } t \text { test): } t\end{array}$} \\
\hline & Mean & SD & Mean & SD & \\
\hline$n$ & \multicolumn{2}{|c|}{131} & \multicolumn{2}{|c|}{69} & \\
\hline Age (years) & $21 \cdot 5$ & $6 \cdot 3$ & $25 \cdot 1$ & $5 \cdot 8$ & 3.98 \\
\hline Duration (years) & $4 \cdot 7$ & $4 \cdot 3$ & 6.9 & $5 \cdot 2$ & $3 \cdot 16^{* *}$ \\
\hline Weight $(\mathrm{kg})$ & 38.7 & $5 \cdot 4$ & $43 \cdot 3$ & $5 \cdot 1$ & 5.86 \\
\hline Height (m) & 1.64 & 0.07 & 1.66 & 0.05 & $2 \cdot 58^{*}$ \\
\hline BMI $\left(\mathrm{kg} / \mathrm{m}^{2}\right)$ & $14 \cdot 5$ & $1 \cdot 6$ & $15 \cdot 7$ & $1 \cdot 5$ & $5 \cdot 32$ \\
\hline \multicolumn{6}{|l|}{ Densitometry } \\
\hline Density $(\mathrm{g} / \mathrm{ml})$ & 1.0694 & 0.0094 & 1.0652 & 0.0104 & $2 \cdot 75^{* *}$ \\
\hline FFM (kg) & 33.9 & $3 \cdot 8$ & 36.8 & $3 \cdot 5$ & $5 \cdot 16$ \\
\hline Fat mass (kg) & $5 \cdot 2$ & $2 \cdot 1$ & 6.5 & 2.5 & 3.85 \\
\hline Body fat $(\%)$ & $12 \cdot 9$ & $4 \cdot 1$ & $14 \cdot 7$ & $4 \cdot 5$ & $2 \cdot 76^{* *}$ \\
\hline \multicolumn{6}{|l|}{ Anthropometry } \\
\hline Density $(\mathrm{g} / \mathrm{ml})$ & 1.0705 & 0.0091 & 1.0644 & 0.0110 & 3.89 \\
\hline FFM (kg) & 33.7 & 3.8 & $36 \cdot 7$ & $3 \cdot 5$ & 5.05 \\
\hline Fat mass (kg) & $4 \cdot 9$ & $2 \cdot 2$ & $6 \cdot 7$ & $2 \cdot 5$ & $5 \cdot 10$ \\
\hline Body fat $(\%)$ & $12 \cdot 4$ & $4 \cdot 5$ & $15 \cdot 1$ & 4.8 & 3.92 \\
\hline Skinfold sum (mm) & 68.2 & $26 \cdot 3$ & $84 \cdot 1$ & $31 \cdot 3$ & 3.79 \\
\hline \multicolumn{6}{|l|}{ Skinfold (mm) } \\
\hline Biceps & 3.52 & 1.55 & $4 \cdot 16$ & $1 \cdot 70$ & $2 \cdot 67^{* *}$ \\
\hline Triceps & $5 \cdot 61$ & $2 \cdot 53$ & 6.88 & 2.79 & 3.26 \\
\hline Subscapula & $5 \cdot 18$ & 1.49 & $6 \cdot 21$ & 1.89 & $4 \cdot 21$ \\
\hline Suprailiac & 3.90 & 1.37 & $4 \cdot 50$ & 1.70 & $2 \cdot 73^{* *}$ \\
\hline Side & $4 \cdot 24$ & $1 \cdot 38$ & $5 \cdot 17$ & 1.94 & 3.89 \\
\hline Waist & $6 \cdot 17$ & 2.90 & $7 \cdot 35$ & 3.57 & $2 \cdot 53^{*}$ \\
\hline Abdomen & 5.42 & $2 \cdot 33$ & 6.03 & $2 \cdot 40$ & $1.74 \mathrm{NS}$ \\
\hline Chin & $4 \cdot 64$ & 1.81 & $5 \cdot 84$ & $2 \cdot 26$ & $4 \cdot 08$ \\
\hline Thigh: Anterior & $8 \cdot 53$ & $4 \cdot 84$ & 11.08 & 5.79 & $3 \cdot 29$ \\
\hline Posterior & $9 \cdot 52$ & 5.03 & $12 \cdot 74$ & $6 \cdot 39$ & 3.92 \\
\hline Calf: Lateral & 6.09 & 3.48 & $7 \cdot 13$ & 3.21 & $2 \cdot 06^{*}$ \\
\hline Medial & 5.49 & $2 \cdot 86$ & $7 \cdot 37$ & 3.52 & $4 \cdot 07$ \\
\hline
\end{tabular}

FFM, fat-free mass.

Mean values for the AN restricters were significantly different from those for the AN bingers and/or purgers (two-tailed $t$ tests): $P<0.000$, except $* P<0.05$, **P<0.01.

$\dagger$ For details of subjects and procedures, see Table 1 and pp. 640-641.

\section{DISCUSSION}

Body composition studies in AN are rare. One of the reasons for this may be the complexity of the semi-starvation state. Most human studies of weight loss have involved obese subjects who are not comparable with AN patients. In anorectics physical exercise, dieting, vomiting and laxative use could affect the body composition (Mitchell \& Truswell, 1987). In addition to this complexity we have to take into account several methodological problems.

A serious problem is the lack of comparability between body composition studies in AN patients concerning, for instance, protein (Russell et al. 1983; Dempsey et al. 1984; Forbes et al. 1984; Pirke et al. 1986), water (Ljunggren et al. 1957; Dempsey et al. 1984; Vaisman 
et al. 1988; Hannan et al. 1990; Casper et al. 1991) and bone density (Forbes et al. 1984; Rigotti et al. 1984; Andersen et al. 1995; Shetty, 1995) due to the use of different techniques. For example, in comparison with a normal control group, the hydration coefficient has been found to be similar (Hannan et al. 1990), lower (Casper et al. 1991) or higher (Vaisman et al. 1988).

A possible error is that the two-compartment model assumes constant densities for FM and FFM. This assumption is generally accepted for FM. In contrast, FFM is composed of several major chemical components such as water, protein, glycogen and various minerals. These components differ in density from each other. Consequently, relative changes in the chemical composition of FFM may change the density of FFM from the assumed value of $1 \cdot 10 \mathrm{~g} / \mathrm{ml}$.

With a decrease in bone-mineral density the use of the Siri (1956) equation results in a possible overestimation of PBF. No method gives an adequate value for the changes of the FFM. Even the most recent dual-energy X-ray absorptiometry (DEXA) method (Heymsfield et al. 1995) does not escape this problem. The data of Roubenoff $e$ t al. (1993) support the concern that in subjects with acute or chronic alterations in body water, DEXA could suffer from important errors in measurements of soft tissue mass (Kohrt, 1995). The result is that errors in fat estimates may occur when using the conversion of D by the application of the Siri (1956) equation in subjects whose density of FFM is not $1.10 \mathrm{~g} / \mathrm{ml}$ (Heymsfield et al. 1995). For want of a good alternative and a specific equation for AN, we have decided to use the much-cited Siri (1956) equation. Of course, an interpretation of PBF data has to take into account the possible influences of considerable variation in the body composition of AN patients. In the future, more specific and homogeneous population studies have to address this problem.

The relationship we found between PBF estimated by SFT and by UWW is in agreement with those given in the literature for normal samples (Womersley et al. 1972; Goris, 1984). UWW was surprisingly well accepted and tolerated by our patients, but it remains a rather unpractical method. SFT measurements give a very good indication of FM and PBF. This method is very useful in clinical practice and field research because it is non-invasive, cheap and easy to apply. A disadvantage is that it has a larger SEE and still requires some training and experience (Lohman, 1981). We conclude, however, that in AN patients the estimation of body fat with SFT can be recommended as a standard procedure. Beside the prediction formula we propose to use the sum of the twelve skinfolds. With this the problems with the different equation formulas can be largely avoided.

There is no general consensus in the literature about the 'normal' PBF for the general female population. PBF averages range between 24 (Jackson \& Pollock, 1985) and $28 \%$ (Mitchell \& Truswell, 1987). Similarly, the values given for 'minimal' PBF for women may vary from 7 to 14 (Behnke \& Wilmore, 1974; Katch et al. 1980; Williams et al. 1984). According to Steinbaugh (1984), a PBF of less than 5 is medically dangerous. Great variations in PBF have been reported in ballet dancers: from 16-17 (Calabrese et al. 1983; Kirkendall \& Calabrese, 1983; Clarkson et al. 1985) to 20-22 (Dolgener et al. 1980; Hergenroeder et al. 1991 a). These results have particular relevance for AN because dancers are considered at risk of developing an eating disorder. The low to very-low PBF values in our sample are similar to those reported in other studies using the same methods (e.g., Davies et al. 1978; Russell et al. 1983; Charest-Lilly et al. 1987; Vaisman et al. 1988; MayoSmith et al. 1989; Casper et al. 1991; Krahn et al. 1993). The reasons for the great range of $\mathrm{PBF}$ are unclear, but may be determined by premorbid body composition (childhood obesity), excessive physical activity during weight loss, or inadequate food intake (severity and/or duration of restriction, quantity and quality of diet; Mitchell \& Truswell, 1987; Garfinkel \& Garner, 1982). 
Our findings in relation to the magnitude of the correlation between BMI and PBF from UWW are in agreement with those of Smalley et al. (1990), Haarbo et al. (1991) and Michielutte et al. (1984), but are higher than those of Brodie \& Slade (1988) and Wang et al. (1984), whereas Cochran et al. (1988) and Heymsfield et al. (1990) found a higher correlation. The relationship between BMI and PBF from SFT was similar to that reported by Brodie \& Slade (1988), Kushner \& Schoeller (1986), Hergenroeder et al. (1991 b) and Heymsfield et al. (1990), but higher than that from the studies by Van Loan \& Mayclin (1987), and Volz \& Ostrove (1984).

BMI reflects real changes in weight: height, but in spite of the high correlation with $\mathrm{PBF}$ it is not a direct index or predictor of relative body fatness (Mitchell \& Truswell, 1987). Hannan et al. (1995) came to similar conclusions in a population of adolescent schoolgirl volunteers and adult female patients. The BMI has only limited significance in the diagnosis of AN. Hannan et al. (1993a) state that target values for FFM may be more appropriate than BMI for assessing the severity of the disorder and its response to treatment. In the light of our results, one may question some recent attempts to define AN in terms of BMI: below 17.5 (American Psychiatric Association, 1994), 16 (Beumont et al. 1988) or 15 (Llewellyn-Jones \& Abraham, 1984).

Our study shows that one should always take clinical variables into account. Unexpectedly, we did not find a difference in PBF between adolescents (postpubertal development) and young adults. Older adults ( $>30$ years) had a higher PBF. This is not due to a difference in the duration of the illness which, contrary to our expectations, does not influence PBF. An important factor is the subtype of AN; we were the first clearly to differentiate results in pure restricters from those in patients who alternate food restriction and binge eating with vomiting and/or purging. It confirms the subclassification defended by Vandereycken \& Pierloot (1983) many years ago on the basis of clinical features and which is now proposed in DSM-IV (American Psychiatric Association, 1994).

\section{REFERENCES}

American Psychiatric Association (1994). Diagnostic and Statistical Manual of Mental Disorders, 4th ed. Washington, DC: American Psychiatric Association.

Andersen, A. E., Woodward, P. J. \& Lafrance, N. (1995). Bone mineral density of eating disorder subgroups. International Journal of Eating Disorders 18, 335-342.

Behnke, A. R. \& Wilmore, J. H. (1974). Evaluation and Regulation of Body Build and Composition. Englewood Cliffs, NJ : Prentice Hall.

Beumont, P. J., Al-Alami, M. \& Touyz, S. (1988). Relevance of a standard measurement of undernutrition to the diagnosis of anorexia nervosa: use of Quetelet's body mass index (BMI). International Journal of Eating Disorders 7, 399-405.

Biersteker, M. W., Boere F. \& Biersteker, P. A. (1983). Het schatten van het gewichtspercentage lichaamsvet met eenvoudige hulpmiddelen (Estimation of percentage body fat with easy devices). Geneeskunde en Sport 16, 29-33.

Brodie, D. A. \& Slade, P. (1988). The relationship between body image and body fat in adult women. Psychological Medicine 16, 623-631.

Brown, W. J. \& Jones, P. R. M. (1977). The distribution of body fat in relation to habitual activity. Annals of Human Biology, 4, 537-550.

Calabrese, L. H., Kirkendall, D. T. \& Floyd, M. (1983). Menstrual abnormalities, nutritional patterns and body composition in female classical ballet dancers. Physician and Sports Medicine 11, 86-98.

Casper, R. C., Schoeller, D. A., Kushner, R., Hnilicka, J. \& Gold, S. T. (1991). Total daily energy expenditure and activity level in anorexia nervosa. American Journal of Clinical Nutrition 53, 1143-1150.

Charest-Lilly, P., Sherill, C. \& Rosentsweig, J. (1987). Body composition of women with anorexia nervosa : a pilot study. Adapted Physical Activity Quarterly 4, 126-136.

Clarkson, P. M., Freedson, P. S., Keller, B., Carney, D. \& Skrinar, M. (1985). Maximal oxygen uptake, nutritional patterns and body composition of adolescent female ballet dancers. Research Quarterly Exercise and Sport 56, 180-184.

Cochran, W. J., Wong, W., Fiorotto, M., Sheng, H., Klein, P. \& Klish, W. J. (1988). Total body water estimated by measuring total body electrical conductivity. American Journal of Clinical Nutrition 48, 946-950. 
Davies, C. T. M., Döbln, W., Fohlin, L., Freyschuss, V. \& Thoren, C. (1978). Total body potassium fat free weight and maximal aerobic power in children with anorexia nervosa. Acta Paediatrica Scandinavica 67, 229-234.

Dempsey, D. T., Crosby, L. O., Lusk, E., Oberlander, J. L., Pertschuk, M. G. \& Muller, J. L. (1984). Total body water and total body potassium in anorexia nervosa. American Journal of Clinical Nutrition 40, $260-269$.

Dolgener, F. A., Spasoff, W. E. \& St John, W. E. (1980). Body build and body composition of high ability female dancers. Research Quarterly Exercise and Sport 51, 599-607.

Durnin, J. V. \& Womersley, J. (1974). Body fat assessed from total body density and its estimation from skinfold thickness: measurements on 481 men and women aged from 16 to 72 years. British Journal of Nutrition 32 , $77-96$.

Forbes, G. B., Kreipe, R. E., Lipinski, B. A. \& Hodgman, C. H. (1984). Body composition changes during recovery from anorexia nervosa: comparison of two dietary regimens. American Journal of Clinical Nutrition 40, 1137-1145.

Garfinkel, P. E. \& Garner, D. (1982). Anorexia Nervosa: A Multidimensional Perspective. New York Brunner/Mazel.

Goris, M. (1984). Toepassingen van de fysiologische antropometrie in de studie van de lichaamssamenstelling en van de trainingseffecten bij jonge volwassene (Applications of physiological anthropometry in the study of body composition and training effects in young adults). Doctoral Dissertation, Catholic University of Leuven.

Haarbo, J., Gotfredsen, A., Hassager, C. \& Christiansen, C. (1991). Validation of body composition by dual energy X ray absorptiometry. Clinical Physiology 11, 331-341.

Hannan, W. J., Cowen, S., Freeman, C. P. \& Shapiro, C. M. (1990). Evaluation of bioelectrical impedance analysis for body composition measurements in anorexia nervosa. Clinical Physics and Physiological Measurement 11, 209-216.

Hannan, W. J., Cowen, S. J., Freeman, C. P. \& Wrate, M. (1993a). Can bioelectrical impedance improve the prediction of body fat in patients with eating disorders? European Journal of Clinical Nutrition 47, 741-746.

Hannan, W. J., Cowen, S. J., Freeman, C. P., Wrate, R. M. \& Barton, J. (1993b). Evaluation of dual-energy Xray absorptiometry for the assessment of body composition in anorexic females. In Human Body Composition, pp. 169-172 [K. J. Ellis and J. D. Eastman, editors]. New York: Plenum Press.

Hannan, W. J., Wrate, R. M., Cowen, S. J. \& Freeman, C. P. (1995). Body mass index as an estimate of body fat. International Journal of Eating Disorders 17, 91-97.

Hergenroeder, A. C., Fiorotto, M. L. \& Klish, W. J. (1991 a). Body composition in ballet dancers measured by total body electrical conductivity. Medicine and Science in Sports and Exercise 23, 528-533.

Hergenroeder, A. C., Wone, M., Fiorotto, M., Smith, E. \& Klish, W. (1991 $b$ ). Total body water and fat free mass in ballet dancers: comparing isotope dilution and Tobec. Medicine and Science in Sports and Exercise 23, 534-541.

Heymsfield, S. B., Wang, J., Funfar, J., Kehayvas, J. J. \& Pierson, R. N. (1990). Dual-photon absorptiometry: comparison of bone mineral and soft tissue mass measurement in vivo with established methods. American Journal of Clinical Nutrition 49, 1283-1289.

Heymsfield, S. B., Allison, D. B., Heshka, S. \& Pierson, R. N. (1995). Assessment of human body composition. In Handbook of Assessment Methods for Eating Behaviors and Weight Related Problems. Measures, Theory and Research, pp. 515-560 [D. B. Allison, editor]. London: Sage Publications.

Jackson, A. S. \& Pollock, M. L. (1985). Practical assessment of body composition. Physician and Sports Medicine 13, 76-89.

Jones, P. R. M., Marshall, W. A. \& Branson, S. J. (1979). Harpenden electric read-out (HERO) skinfold calipers. Annals of Human Biology 6, 159-162.

Katch, F. I., Katch, V. L. \& Behnke, A. R. (1980). The underweight female. Physician and Sports Medicine 8 , $55-60$.

Kirkendall, D. T. \& Calabrese, C. H. (1983). Physiologic aspects of dance. Clinical Sports Medicine 2, 525-537.

Kohrt, W. M. (1995). Body composition by DXA: tried and true? Medicine and Science in Sports and Exercise 27, 1349-1353.

Krahn, D. D., Rock, C., Dechert, R. E., Nairn, K. K. \& Hasse, S. A. (1993). Changes in resting energy expenditure and body composition in anorexia nervosa patients during refeeding. Journal of the American Dietetics Association 93, $434-438$.

Kushner, R. F. \& Schoeller, D. A. (1986). Estimation of total body water by bioelectrical impedance analysis. American Journal of Clinical Nutrition 44, 417-424.

Lasser, R. B., Bond, J. H. \& Levitt, M. D. (1975). The role of intestinal gas in functional abdominal pain. New England Journal of Medicine 293, 524-526.

Lasser, R. B., Levitt, M. D. \& Bond, J. H. (1976). Studies of intestinal gas after ingestion of a standard meal. Gastroenterology 70, A-48/906.

Leusink, J. A. (1974). A comparison of the body composition estimated by densitometry and total body potassium measurement in trained and untrained subjects. Pfiugers Archives 348, 357-362.

Ljunggren, H., Ikkos, D. \& Luft, R. (1957). Studies on composition III. Body fluid compartments and exchangeable potassium in females with anorexia nervosa. Acta Endocrinology Scandinavica 25, 209-233.

Llewellyn-Jones, D. \& Abraham, S. F. (1984). Quetelet index in diagnosis of anorexia nervosa. British Medical Journal 288, 1800. 
Lohman, T. G. (1981). Skinfold and body density and their relation to body fatness: A review. Human Biology $53,181-225$.

Mayo-Smith, W., Hayes, C. W., Biller, B., Klibanski, A., Rosenthal, H. \& Rosenthal, D. (1989). Body fat distribution measured with CT: correlations in healthy subjects, patients with anorexia nervosa, and patients with Cushing syndrome. Radiology 170, 515-518.

Michielutte, R., Diseker, R. A., Corbitt, W. T., Schey, H. M. \& Ureda, J. R. (1984). The relationship between weight-height indices and the triceps skinfold measure among children aged 5-12. American Journal of Public Health 74, 604-606.

Mitchell, P. B. \& Truswell, A. S. (1987). Body composition in anorexia nervosa and starvation. In Handbook of Eating Disorders. Part 1: Anorexia and Bulimia Nervosa, pp. 45-77 [P. J. V. Beumont, G. D. Burrows \& R. C. Casper, editors]. Amsterdam: Elsevier.

Pirke, K. M., Pahl, J., Münzing, W., Lang, P. \& Büll, U. (1986). Total body potassium, intracellular potassium and body composition in patients with anorexia nervosa during refeeding. International Journal of Eating Disorders 5, 347-354.

Probst, M., Van Coppenolle, H. \& Vandereyken, W. (1995). Body experience in anorexia nervosa patients: an overview of therapeutic approaches. Eating Disorders 3, 145-157.

Rigotti, N. A., Nussbaum, S. R., Herzog, D. B. \& Neer, R. M. (1984). Osteoporosis in women with anorexia nervosa. New England Journal of Medicine 311, 1601-1606.

Roubenoff, R., Kehayias, J. J., Dawson-Hughes, B. \& Heymsfield, S. B. (1993). American Journal of Clinical Nutrition 58, 589-591.

Russell, J. D., Mira, M., Allen, B. J., Stawart, P. M., Vizzard, J., Arthur, B. \& Beumont, P. J. (1994), Protein repletion and treatment in anorexia nervosa. American Journal of Clinical Nutrition, 59, 98-102.

Russell, D., Prendergast, P. J., Darby, P. L., Garfinkel, P. E., Whitewell, J. R. \& Jeejeebhoy, K. N. (1983). A comparison between muscle function and body composition in anorexia nervosa: the effect of refeeding. American Journal of Clinical Nutrition 38, 229-237.

Shetty, P. S. (1995). Body composition in health and disease. In Society for the Study of Human Biology: Symposium no. 36, pp. $71-84$ [P.S. W. Davies and T. J. Cole, editors]. Cambridge: Cambridge University Press.

Siri, W. E. (1956). The gross composition of the body. In Advances in Biological and Medical Physics, pp. 239-280 [J. H. Lawrence and C. A. Tobias, editors]. New York: Academic Press.

Smalley, K. J., Knerr, A. N., Kendrick, Z. V., Colliver, J. A. \& Owen, O. E. (1990). Reassessment of body mass indices. American Journal of Clinical Nutrition 52, 405-408.

Statsoft Inc. (1991). Statistica. Tulsa, OK: Statsoft Inc.

Steinbaugh, M. (1984). Nutritional needs of female athletes. Clinics in Sports Medicine 3, 649-670.

Vaisman, N., Corey, M., Rossi, M. F., Goldberg, E. \& Pencharz, P. (1988). Changes in body composition during refeeding of patients with anorexia nervosa. Journal of Pediatrics 113, $925-929$.

Vaisman, N., Rossi, M., Corey, M., Clarke, R., Goldberg, E. \& Pencharz, B. (1991). The effect on the energy metabolism of adolescent girls who have anorexia nervosa. European Journal of Clinical Nutrition 45, 527-537.

Vandereycken, W. \& Meermann, R. (1984). Anorexia nervosa: A Clinican's Guide to Treatment. New York: Walter de Gruyter.

Vandereycken, W.\& Pierloot, R. (1983). The significance of subclassification in anorexia nervosa: a comparative study of clinical features in 141 patients. Psychological Medicine 13, 543-549.

Van Loan, M. D. \& Mayclin, P. (1987). A new Tobec instrument and procedure for the assessment of body composition. American Journal of Clinical Nutrition 45, 131-137.

Volz, P. A. \& Ostrove, S. M. (1984). Evaluation of a portable ultranoscope in assessing the body composition of college-age women. Medicine and Science in Sports and Exercise 16, 97-102.

Wang, J., Heymsfield, S. B., Aulet, M., Thornton, J. C. \& Pierson, R. N. Jr (1984). Body fat from body density: underwater weighing versus dual photon absorptiometry. American Journal of Physiology 256, E829-E834.

Womersley, J., Boddy, K., King, P. C. \& Durnin, J. V. (1972). A comparison of the fat-free mass of young adults estimated by anthropometry, body density and total body potassium content. Clinical Science 43, 469-475.

Weiner, J. S. \& Lourie, J. A. (1969). Human Biology. A Guide to Field Methods. Edinburgh: Blackwell Scientific Publications Ltd.

Williams, D., Anderson, T. \& Currier, D. (1984). Underwater weighing using the Hubbard tank versus the standard tank. Physical Therapy 64, 658-663.

Young, N., Formica, C. \& Szmukler, G. (1994). Bone density and weight-bearing and nonweight-bearing site in ballet dancers: the effect of exercise, hypogonadism and body weight. Journal of Clinical Endrocrinology and Metabolism 78, 449-454, 